\title{
Trombolytisk behandling ved hjerneinfarkt
}

\begin{abstract}
Sammendrag
Bakgrunn. Intravenøs trombolytisk behandling har de siste ti årene fått stor utbredelse og er den eneste godkjente, spesifikke behandlingen ved akutt hjerneinfarkt. Haukeland universitetssykehus innførte den i 1998. Formålet med artikkelen er å beskrive våre erfaringer fra de første 100 pasientene med infarkt i arteria cerebri medias forsyningsområde behandlet med intravenøs trombolyse.
\end{abstract}

Materiale og metode. I vår trombolysedatabase inkluderte vi prospektivt alle pasienter som i perioden 1998-2005 fikk intravenøs trombolytisk behandling. Vi registrerte demografiske data, risikofaktorer, tidsaspekter, kliniske korttids- og langtidsresultater samt komplikasjoner.

Resultater. Tydelig klinisk bedring ble registrert hos $30 \%$ av pasientene to timer etter behandling og hos $49 \%$ 24 timer etter. $2 \%$ av pasientene hadde symptomgivende blødning. Tre pasienter ble hemikraniektomert på grunn av massivt hjerneødem med truende herniering. Etter tre måneder fremviste $55 \%$ av pasientene et godt resultat (uavhengighet), mens $13 \%$ var døde. Gjennomsnittlig tid fra iktus til trombolytisk behandling gikk ned fra 166 til 142 minutter.

Fortolkning. Resultatene fra de første 100 trombolysebehandlede slagpasientene på Haukeland universitetssykehus er sammenliknbare med store internasjonale studier, både med tanke på andel pasienter med fordelaktig resultat og med tanke på komplikasjoner. Våre erfaringer understøtter at intravenøs trombolytisk behandling er en effektiv og sikker rutinebehandling ved en slagenhet.

> Se også side 2213

\section{Viktoria Varga}

viktoria.varga@helse-bergen.no

Ulrike Waje-Andreassen

Halvor Næss

Nevrologisk avdeling

Haukeland universitetssykehus 5021 Bergen

Maria Therese Lundstadsveen

Det medisinske fakultet

Universitetet i Bergen

\section{Lars Thomassen}

Nevrologisk avdeling

Haukeland universitetssykehus

Hjerneslag rammer 12 000-14 000 mennesker i Norge hvert år. Sykdommen er ansvarlig for rundt $10 \%$ av dødsfallene $i$ industrielle land og er den nest vanligste dødsårsaken globalt (1). Omtrent $1 / 3$ av de som overlever blir fysisk funksjonshemmet og avhengig av hjelpemidler lenger enn ett år (2).

Intravenøs trombolyse med rekombinant vevsplasminogenaktivator (tPA; alteplase) er i dag den eneste dokumentert effektive medikamentelle behandlingen ved akutt hjerneinfarkt. Målet for trombolytisk behandling er å rekanalisere en okkludert arterie. Rekanalisering er raskere hos pasienter behandlet med trombolyse enn hos pasienter uten slik behandling (3). Vi har tidligere vist at rekanalisering er assosiert med godt langtidsresultat (4). Dette er også vist av andre (5).

Flere randomiserte studier har bekreftet at behandling med rekombinant vevsplasminogenaktivator innen tre timer etter iktus er trygt og effektivt (6-10). Alteplase ble godkjent for behandling av hjerneinfarkt i USA i 1996, Canada 1999, EU 2002 og i Norge i 2003. Nevrologisk avdeling ved Haukeland universitetssykehus etablerte trombolytisk behandling som standard i mai 1998 (11).

Vi presenterer i denne artikkelen resultatene hos de første 100 pasientene med infarkt i arteria cerebri medias forsyningsområde som fikk trombolytisk behandling.

\section{Materiale og metode}

Alle pasienter som i perioden mai 1998 - desember 2005 ble innlagt ved Haukeland universitetssykehus med akutt hjerneslag ble vurdert med tanke på trombolytisk behandling dersom de var innenfor alders- og tidsrammen for slik behandling. Etisk komité vurderte behandlingsprosjektet i 1998, men anså det som innføring av en ny behandlingsmetode og noe som lå utenfor komi- teens mandat. Behandlingen ble gitt utenfor godkjent indikasjon, men pasientene eller pårørende ga samtykke til behandling (1998-2003) og registrering (2003-05). Fra 2003 ble data registrert i forbindelse med SITS-studien (Safe Implementation of Thrombolysis in Stroke). Inklusjons- og ekslusjonskriterier for trombolyse var basert på National Institute of Neurological Disorders and Stroke (NINDS) rtPA-studien (10), European-Australian Cooperative Acute Stroke Study (ECASS og ECASS II) $(8,9)$, og fra 2003 ble de modifisert i henhold til europeiske retningslinjer (12).

Viktigste inklusjonskriterium var behandlingsstart innen tre timer fra symptomstart. CT av hjernen ble utført raskest mulig for å utelukke blødning og for å vurdere tidlige infarkttegn, slik som hyperdens a. cerebri media, hypodensitet i basalgangliene, tegn til utvisket kortikalt relieff og ødemforandringer i det affiserte området (13). Transkranial dopplerundersøkelse (TCD) ble foretatt når dette var praktisk mulig. Nevrologiske utfall ble kvantitativt skåret med National Institute of Health Stroke Scale (NIHSS) (14), der 0 representerer ingen utfall, 1-7 lette utfall, $8-14$ moderate $o g \geq 15$ alvorlige utfall. Klinisk klassifikasjon ble utført i henhold til Oxfordshire Community Stroke Project (OCSP). Pasientene ble gruppert avhengig av om de klinisk hadde et totalt fremre kretsløpssyndrom (TACS), partielt fremre kretsløpssyndrom (PACS) eller lakunært syndrom (LACS) (15).

Trombolytisk behandling ble gitt etter vurdering av CT-bilder og kliniske funn. Doseringen av alteplase var $0,9 \mathrm{mg} / \mathrm{kg} .10 \%$ av den totale dosen ble gitt som bolus, resten som intravenøs infusjon i løpet av 60 minutter. Platehemmer og heparin ble ikke gitt de påfølgende 24 timene.

Blodtrykk, puls, temperatur og oksygenmetning ble observert nøye. Blodtrykk > $185 \mathrm{~mm} \mathrm{Hg}$ systolisk eller $>110 \mathrm{~mm} \mathrm{Hg}$ dia-

\section{Hovedbudskap}

- Intravenøs trombolytisk behandling er trygt og effektivt ved akutt hjerneinfarkt

- I daglig rutine er kliniske resultater gode og komplikasjonsraten lav

- Trombolytisk behandling må tilbys ved alle sykehus som behandler akutt hjerneslag 
stolisk ble senket med intravenøs labetalol før trombolyse ble gitt. I 2003 ble nye EUregler innført og tatt i bruk. Ifølge disse var det ikke indikasjon for trombolytisk behandling dersom det var behov for medikamentell redusering av blodtrykket. Ved temperatur $>37,5{ }^{\circ} \mathrm{C}$ fikk pasienten paracetamol. Blodsukker $>12 \mathrm{mmol} / 1$ (fra 2003: $>8 \mathrm{mmol} / \mathrm{l}$ ) ble senket med hurtigvirkende insulin, uavhengig av eventuell diabetesdiagnose. Nevrologisk status ble vurdert ved NIHSS-skår før behandling samt etter to og 24 timer. Et fall på minst ti NIHSS-poeng ble definert som betydelig bedring, et fall på 4-9 poeng som klinisk signifikant og 1-3 poeng som minimal bedring.

Infarktutbredelse og eventuelle blødninger ble ett døgn etter trombolyse rutinemessig vurdert ved en kontroll-CT, men ved klinisk forverring ble det tatt ny CT også tidligere. Blødninger ble radiologisk definert som hemoragisk infarkt eller parenkymatøst hematom. Symptomgivende blødning ble definert som et parenkymatøst hematom parallelt med en klinisk forverring på minst fire poeng i NIHSS. T-test ble benyttet for statistiske analyser vedrørende risikofaktorer for blødning. Risikofaktorer som hypertensjon, diabetes mellitus, hyperlipidemi, atrieflimmer, iskemisk hjertesykdom, tidligere cerebrovaskulær sykdom, røyking og vekt ble registrert etter vanlige definisjoner (16).

Langtidsoppfølging etter tre måneder ble foretatt av en spesialopplært slagsykepleier ved hjelp av et strukturert telefonintervju (17-19). Følgetilstanden ble skåret med modifisert Rankin-skala (mRS) (ramme 1). Langtidsresultatene ble vurdert $i$ en enhetlig analyse (uniform analysis), der et godt resultat, uavhengig av utgangspunktet, defineres som mRS $0-2$, et dårlig resultat som mRS $3-5$ og 6 representerer død. Vi benyttet også responsanalyse (responder analysis), der et meget godt resultat (excellent outcome) relateres til NIHSS-skår ved utgangspunktet $(18,20)$. Hos pasienter med lette utfall i utgangspunktet (NIHSS 1-7) er et meget godt resultat en mRS-skår på 0 , ved moderate utfall (NIHSS 8-14) er et meget godt resultat mRS $0-1$, og ved alvorlige utfall (NIHSS $\geq 15$ ) mRS $0-2$.

Vi registrerte tidsforbruk fra iktus til trombolytisk behandling, delt inn i tid fra iktus til sykehus, til første legeundersøkelse, til første CT-undersøkelse og til administrasjon av trombolyse. For å synliggjøre forandringer i tidsbruk har vi delt seksårsperioden i tre bolker (1998-2000, 2001-02 og 2003-05).

\section{Resultater}

I den aktuelle perioden oppfylte 100 pasienter, 63 menn og 37 kvinner, med alder 18-80 år (median 68 år) kriteriene for trombolysebehandling (tab 1) $(7,12) .64$ pasienter hadde venstresidig a. cerebri media-infarkt, 34 høyresidig og to hadde bilaterale infarkter. $50 \%$ av pasientene hadde $\geq 3$ risi- kofaktorer, $21 \%$ hadde $\geq 4$. Av 46 pasienter med hypertensjon var $44(96 \%)$ medikamentelt behandlet, $13(43 \%)$ av 30 pasienter med hyperkolesterolemi var medikamentelt behandlet, og én ( $3 \%)$ av 31 pasienter med atrieflimmer hadde fått antikoagulasjonsbehandling. 35 pasienter røykte, ti hadde diabetes og 28 pasienter hadde kjent cerebrovaskulær sykdom. Platehemmere ble brukt av 37 pasienter.

Pasientene hadde ved innleggelse en median NIHSS-skår på 13 (gjennomsnitt 14, spredning 2-28). 54 pasienter ble undersøkt med transkranial doppler ved innleggelsen. Gruppering av pasientene etter graden av nevrologiske utfall ved innleggelse, etter to timer og 24 timer er fremstilt i figur 1. Endring av pasientenes kliniske tilstand de første 24 timene er fremstilt i figur 2.

55 pasienter hadde kliniske symptomer som tilsvarte totalt fremre kretsløpssyndrom (TACS), 34 partielt fremre kretsløpssyndrom (PACS) og ti lakunært syndrom (LACS).

Hos ti pasienter tilkom blødning. Tre av disse hadde hemoragisk infarkt, tre hadde en mindre parenkymatøs blødning, tre hadde en stor parenkymatøs blødning og én pasient fikk en fjernblødning i pons. Det var en assosiasjon mellom blødning og lavt antall trombocytter $(p=0,029)$ og en tendens til høy glukose $(\mathrm{p}=0,065)$. Pasienter med parenkymatøs blødning uten masseeffekt hadde alle en mindre bedring i NIHSS-skår etter 24 timer, én pasient oppnådde mRS 1, mens de to andre oppnådde mRS 3 etter tre måneder. To pasienter fikk symptomgivende blødning, og de døde etter henholdsvis 16 og 18 døgn. Alle de tre pasientene med hemoragisk infarkt hadde en bedring av NIHSSskår på minst seks poeng etter 24 timer $(6,7$ og 7) og hadde etter tre måneder henholdsvis mRS 5, 1 og 3. Av disse tre hadde kun én blodtrykk $>185 / 110$, men det ble ikke gitt intravenøs labetalol under prosedyren. Ingen fikk antitrombotisk behandling.

Tre pasienter (alder 36, 58 og 64 år) med initial NIHSS-skår på henholdsvis 24, $22 \mathrm{og}$ 20 utviklet massivt hjerneødem med truende

\section{Ramme 1}

\author{
Modifisert Rankin-skala (mRS) \\ $\mathrm{mRS} 0=$ Ingen symptomer \\ mRS 1 = Lette symptomer, men ingen \\ begrensninger $\mathrm{i}$ dagliglivet \\ mRS 2 = Sosiale begrensninger, men \\ uavhengig av hjelpemidler \\ mRS 3 = Behov for hjelpemidler, men \\ oppegående \\ mRS $4=$ Avhengig av hjelpemidler \\ mRS 5 = Sengeliggende med behov for \\ kontinuerlig hjelp \\ $\mathrm{mRS} 6=\mathrm{D} ø \mathrm{~d}$
}

herniering og ble hemikraniektomert. Ingen av dem viste nevrologisk bedring etter trombolysebehandling og de viste kun bedring av bevissthetsnivået etter hemikraniektomi. Etter tre måneder oppnådde disse pasientene mRS-skår på 3, 4 og 5.

Ved analyse etter tre måneder oppnådde $39 \%$ av pasientene et meget godt resultat (mRS 0-1), 55\% oppnådde et godt resultat (mRS $0-2), 31 \%$ et dårlig resultat (mRS $3-5)$ og $13 \%$ var døde (fig 3) $(7,12)$. Ved responsanalyse forelå et meget godt resultat hos $32 \%$ (7 av 22) i gruppen med NIHSSskår 1-7, 37 \% (13 av 35) av dem med NIHSS $8-14$ og $33 \%$ (14 av 43) av dem med NIHSS $\geq 15$. Samlet oppnådde dermed $34 \%$ av pasientene et meget godt resultat ved responsanalysen. I løpet av studieperiodene 1998-2000, 2001-02 og 2003-05 var det liten endring i gjennomsnittlig tid fra iktus til innkomst i sykehus (66-71-63 minutter), mens gjennomsnittlig tid fra akuttmottak til CT-lab (36-28-25 minutter), fra CT til sengepost (45-32-32 minutter) og fra ankomst sengepost til trombolyse (23-20-19 minutter) ble redusert. Både gjennomsnittlig totalt tidsforbruk på sykehuset (108-84-82 minutter) og tidsforbruk fra iktus til trombo-

Tabell 1 Sammenlikning av pasientkarakteristika mellom samleanalyse av randomiserte kontrollerte studier (7). Safe Implementation of Thrombolysis in Stroke Monitoring Study (SITS-MOST) (12) og Haukeland universitetssykehus. NIHSSS = National Institute of Health Stroke Scale Score

\begin{tabular}{lccc} 
& & & Haukeland \\
& Samleanalyse & SITS-MOST & universitetssykehus \\
\hline Alder lår, median) & 70 & 68 & 68 \\
\hline Kvinner (\%) & 40 & 40 & 37 \\
\hline Hypertensjon (\%) & 60 & 59 & 46 \\
\hline Diabetes mellitus (\%) & 21 & 16 & 10 \\
\hline Atrieflimmer (\%) & 21 & 24 & 31 \\
\hline Tidligere cerebrovaskulær sykdom (\%) & 14 & 10 & 28 \\
\hline NIHSSS 1-7 (\%) & & 23 & 22 \\
\hline NIHSSS 8-14 (\%) & & 37 & 35 \\
\hline NIHSSS $\geq 15(\%)$ & 40 & 43
\end{tabular}




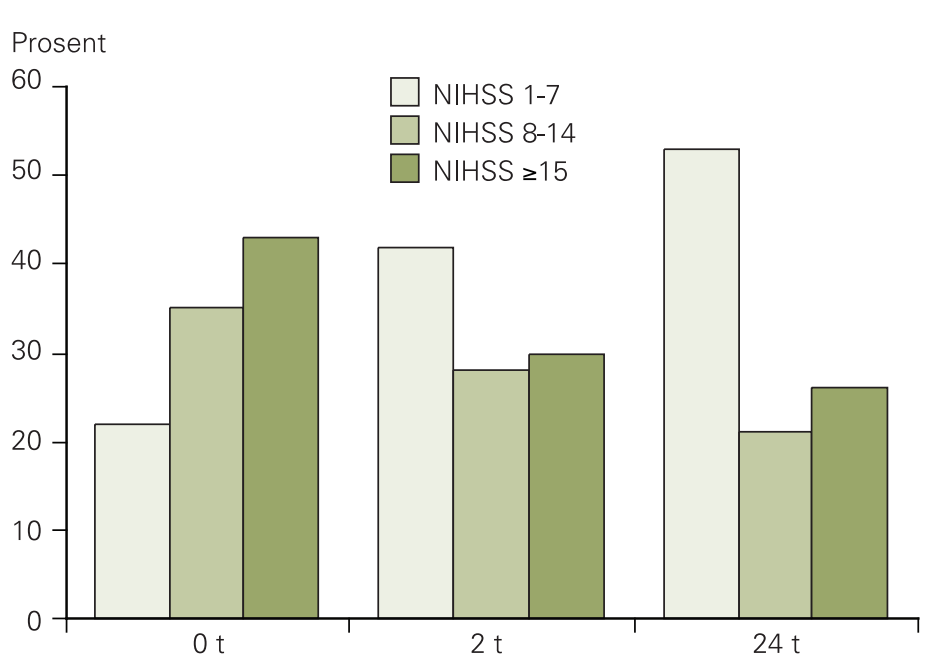

Figur 1 Gruppering av pasientene etter graden av nevrologiske utfall ved innleggelse, etter to og 24 timer, målt ved skår på National Institute of Health Stroke Scale (NIHSS). NIHSS 1-7 = lette utfall, NIHSS 8-14= moderate utfall, NIHSS $\geq 15$ = alvorlige utfal lyse (166-155-142 minutter) er redusert. I 2000 ble ni pasienter undersøkt med MR som primærundersøkelse i stedet for CT. Dette medførte forlenget tidsbruk fra akuttmottak til trombolyse. Vi valgte derfor å ha CT som standard initial radiologisk undersøkelse videre.

\section{Diskusjon}

Blant våre pasienter ble $49 \%$ markant bedre i løpet av det første døgnet etter trombolytisk behandling. Vi har ved transkranial ultralyd tidligere vist at rekanalisering innen 24 timer kan opptre hos $70 \%$ av trombolysebehandlede pasienter og at rekanalisering er assosiert med klinisk bedring $(4,21)$. Ultralyd kan i seg selv øke rekanaliseringsraten (22), og våre kliniske data kan derfor være påvirket av ultralyddiagnostikken under trombolysen.
Blødninger oppsto i forskjellig grad hos $10 \%$ av pasientene. Langtidsresultatene varierte. Det er påvist en assosiasjon mellom hemoragisk infarkt og bedret langtidsresultat, noe som indikerer at en hemoragisk transformasjon av infarktet representerer tidlig rekanalisering (23). Mindre blødninger er derfor ikke ensbetydende med negativ langtidseffekt.

To pasienter hadde symptomgivende blødning. Ifølge Safe Implementation of Thrombolysis in Stroke Monitoring Study (SITS-MOST) opptrer symptomgivende hjerneblødning hos $1,7-2,2 \%$ av pasientene, men dette er avhenging av benyttet definisjon. I henhold til definisjonen fra NINDS-studien (24), dvs. enhver blødning på CT kombinert med enhver nevrologisk forverring, hadde $3 \%$ av våre pasienter en symptomgivende blødning. I SITS-MOST

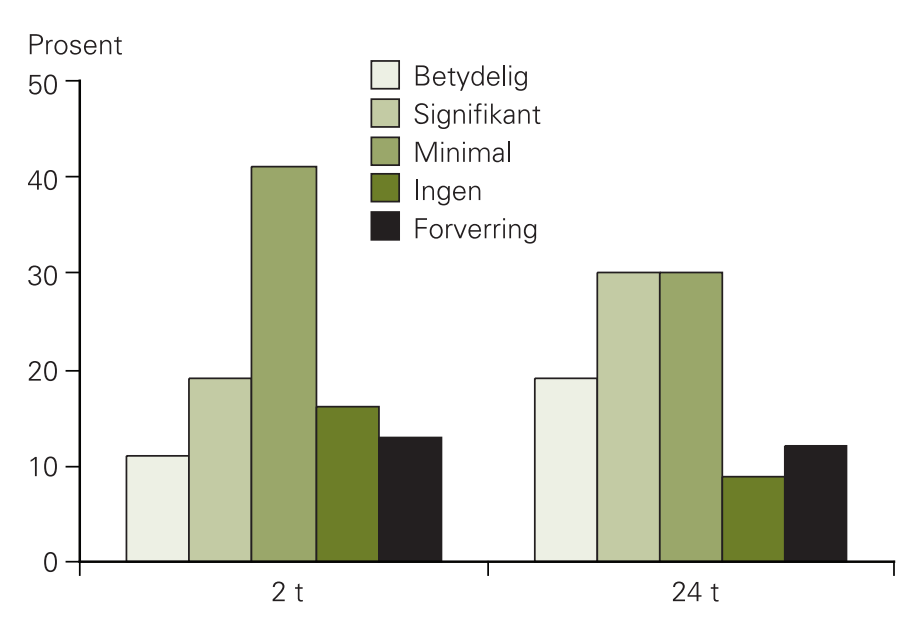

Figur 2 Endring av skår på National Institute of Health Stroke Scale (NIHSS) etter to og 24 timer. Endring er definert som betydelig bedring ( $\geq 10$ poeng), signifikant bedring ( $\geq 4$ poeng), minimal bedring (1-3 poeng), ingen endring og forverring var tilsvarende andel 7,3\%. Faktorer som predikerer symptomgivende blødning er høy NIHSS-skår ved innkomst, høyt blodtrykk, hyperglykemi, utbredte tidlige CT-forandringer og høy alder (25). I vårt materiale fant vi en assosiasjon mellom blødning og lavt antall trombocytter $(\mathrm{p}=0,029)$, og en tendens ved høye glukosenivåer $(p=0,065)$, men ellers ingen faktorer signifikant assosiert med blødningskomplikasjoner.

Stort hjerneødem med truende herniering er en alvorlig komplikasjon som kan opptre i inntil $10 \%$ av supratentorielle infarkter (26). Tilstanden er assosiert med en mortalitet opp mot $80 \%$. I vårt materiale utviklet tre pasienter denne komplikasjonen. Felles for dem var alvorlige utfall ved innkomst og relativt ung alder. To hadde infarktet $i$ venstre, og en i høyre hemisfære. Alle ble behandlet med hemikraniektomi, men hadde til tross for dette dårlig funksjonsevne etter tre måneder, og én av dem døde etter ett år. Det er likevel rapportert at pasienter som får trombolytisk behandling kan oppnå bedre funksjonsnivå etter hemikraniektomi enn dem som er konservativt behandlet (27).

Tallene er små, men våre data kan tyde på høyere risiko for blødning hos eldre pasienter med komorbiditet og hypertensjon, og høyere risiko for malignt ødem hos yngre pasienter med store infarkter.

Våre langtidsresultater er i overensstemmelse med data fra internasjonale studier. Resultatene er noe bedre enn i de randomiserte studiene (7), men disse studiene er mer enn ti år gamle, og våre resultater er sannsynligvis påvirket av en generelt forbedret behandling av hjerneinfarkt de siste årene. Det er også en klar trend mot færre pasienter med hypertensjon og diabetes mellitus i vårt materiale, sammenliknet med andre randomiserte studier (tab 1). Våre resultater samsvarer godt med dem fra SITS-MOST (12), som representerer de nyeste behandlingsdata. Samlet synes vår populasjon å være representativ sammenliknet med de internasjonalt publiserte data.

Nøyaktig registrering av tidsbruk muliggjør analyse av logistiske utfordringer og områder med forbedringspotensial. Tid fra iktus til ankomst i sykehus er ikke redusert $i$ studieperioden, til tross for informasjonskampanjer og omtale i mediene. Innad i sykehuset var det imidlertid en forbedring $i$ alle ledd, mest tydelig i tidsbruk fra initial legeundersøkelse til CT. Total tid fra iktus til trombolytisk behandling ble derfor allikevel noe redusert.

\section{Konklusjon}

Resultatene fra de første 100 trombolysebehandlede pasientene på Haukeland universitetssykehus er sammenliknbare med resultatene fra store internasjonale randomiserte studier og store kliniske åpne behandlingsserier, både med tanke på andel pasienter med fordelaktig resultat og med tanke på komplikasjoner og død. Trombolytisk be- 


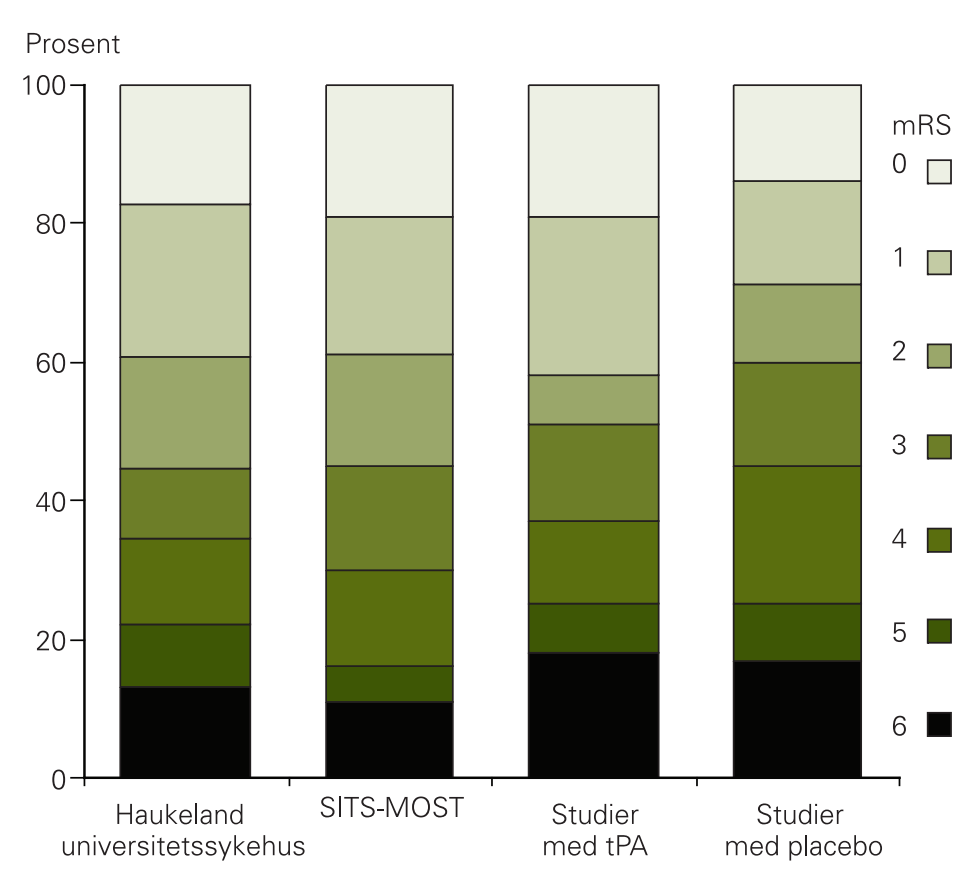

Figur 3 Sammenlikning av klinisk langtidsresultat etter tre måneder mellom Haukeland universitetssykehus, Safe Implementation of Thrombolysis in Stroke Monitoring Study (SITS-MOST) (12) og samleanalyse av randomiserte kontrollerte studier med en trombolysegruppe (tPA) og en placebogruppe (7). $m R S=$ modifisert Rankin Scale. $m R S 0-2=$ uavhengighet, $m R S$ 3-5 = avhengighet, $m R S 6$ = død

handling ved akutt hjerneinfarkt som rutine synes derfor å være en tilfredsstillende trygg og effektiv behandling.

Oppgitte interessekonflikter: Lars Thomassen har mottatt forelesningshonorarer fra Boehringer Ingelheim for forelesninger om akutt hjerneinfarkt og trombolytisk behandling. Han har også mottatt dekning av utgifter fra Boehringer Ingelheim til slagkongresser. Ulrike Waje-Andreassen er blitt invitert av Boehringer Ingelheim til å delta på europeiske slagkongresser. De øvrige forfatterne har ingen oppgitte interessekonflikter.

\section{Litteratur}

1. Pendlebury ST, Rothwell PM, Algra A et al. Underfunding of stroke research: a Europe-wide problem. Stroke 2004: 35: 2368-71.

2. MacDonald BK, Cockerell OC, Sander JW et al. The incidence and lifetime prevalence of neurological disorders in a prospective community-based study in the UK. Brain 2000; 123: 665-76.

3. Gerriets T, Postert T, Goertler M et al. DIAS I: duplex-sonographic assessment of the cerebrovascular status in acute stroke. A useful tool for future stroke trials. Stroke 2000; 31: 2342-5.
4. Thomassen L, Waje-Andreassen U, Naess $\mathrm{H}$ et al. Doppler ultrasound and clinical findings in patients with acute ischemic stroke treated with intravenous thrombolysis. Eur J Neurol 2005; 12: 462-5.

5. Wunderlich MT, Goertler M, Postert T et al. Recanalization after intravenous thrombolysis: does a recanalization time window exist? Neurology 2007; 68: $1364-8$

6. Clark WM, Albers GW, Madden KP et al. The rtPA lalteplase) 0- to 6-hour acute stroke trial, part A (A0276g) : results of a double-blind, placebo-controlled, multicenter study. Thrombolytic therapy in acute ischemic stroke study investigators. Stroke 2000; $31: 811-6$.

7. Hacke W. Donnan G. Fieschi C et al. Association of outcome with early stroke treatment: pooled analysis of ATLANTIS, ECASS, and NINDS rt-PA stroke trials. Lancet 2004; 363: 768-74.

8. Hacke W, Kaste M, Fieschi C et al. Intravenous thrombolysis with recombinant tissue plasminogen activator for acute hemispheric stroke. The European Cooperative Acute Stroke Study (ECASS). JAMA 1995; 274: 1017-25.

9. Hacke W. Kaste M. Fieschi $\mathrm{C}$ et al. Randomised double-blind placebo-controlled trial of thrombolytic therapy with intravenous alteplase in acute ischaemic stroke (ECASS II). Second EuropeanAustralasian Acute Stroke Study Investigators. Lancet 1998; 352: 1245-51.

10. NINDS. NINDS rt-PA Stroke Study Group. Tissue plasminogen activator for acute ischemic stroke. N Engl J Med 1995; 333: 1581-7.
11. Thomassen L, Waje-Andreassen U, Maintz C Trombolytisk behandling ved akutt hjerneinfarkt en tidsstudie ved organisering av et nytt behandlingstilbud. Tidsskr Nor Lægeforen 1999; 119: 2978-81.

12. Wahlgren N, Ahmed N, Davalos A et al. Thrombolysis with alteplase for acute ischaemic stroke in the Safe Implementation of Thrombolysis in Stroke-Monitoring Study (SITS-MOST): an observational study. Lancet 2007: 369: 275-82.

13. Waje-Andreassen U, Thomassen L, Smievoll Al. Tidlige CT-forandringer ved akutt hjerneinfarkt. Tidsskr Nor Lægeforen 2001; 121: 1591-3.

14. Brott T, Adams HP jr., Olinger CP et al. Measurements of acute cerebral infarction: a clinical examination scale. Stroke 1989; 20: 864-70.

15. Wardlaw JM, Dennis MS, Lindley RI et al. The validity of a simple clinical classification of acute ischaemic stroke. J Neurol 1996; 243: 274-9.

16. Phillips RA. A review of therapeutic strategies for risk reduction of recurrent stroke. Progress in cardiovascular diseases 2008; 50: 264-73.

17. Thomassen L, Waje-Andreassen U, Morsund AH et al. Thrombolytic therapy in acute ischaemic stroke. Cerebrovasc Dis 2002; 13: 163-7.

18. Thomassen L, Waje-Andreassen U, Naess $\mathrm{H}$ et al. Long-term effect of intravenous thrombolytic therapy in acute stroke: responder analysis versus uniform analysis of excellent outcome. Cerebrovasc Dis 2005; 20: $470-4$.

19. Thomassen L, Waje-Andreassen U, Næss $\mathrm{H}$ et al. Trombolytisk behandling ved akutt hjerneinfarkt. Tidsskr Nor Lægeforen 2002: 122: 2095-7.

20. Saver JL. Novel end point analytic techniques and interpreting shifts across the entire range of outcome scales in acute stroke trials. Stroke 2007; 38: $3055-62$.

21. Tandberg Askevold E, Naess H, Thomassen L. Predictors for recanalization after intravenous thrombolysis in acute ischemic stroke. J Stroke Cerebrovasc Dis 2007; 16: $21-4$

22. Alexandrov AV, Molina CA, Grotta JC et al. Ultrasound-enhanced systemic thrombolysis for acute ischemic stroke. N Engl J Med 2004; 351: 2170-8

23. Molina CA, Alvarez-Sabin J, Montaner J et al. Thrombolysis-related hemorrhagic infarction: a marker of early reperfusion, reduced infarct size, and improved outcome in patients with proximal middle cerebral artery occlusion. Stroke 2002; 33 $1551-6$.

24. NINDS. Intracerebral hemorrhage after intravenous t-PA therapy for ischemic stroke. The NINDS t-PA Stroke Study Group. Stroke 1997; 28 : 2109-18.

25. Thiis VN, Lansberg MG, Beaulieu $C$ et al. Is early ischemic lesion volume on diffusion-weighted imaging an independent predictor of stroke outcome? A multivariable analysis. Stroke 2000; 31: 2597-602.

26. Bardutzky J, Schwab S. Antiedema therapy in ischemic stroke. Stroke 2007: 38: 3084-94.

27. Rabinstein AA, Mueller-Kronast N, Maramattom $\mathrm{BV}$ et al. Factors predicting prognosis after decompressive hemicraniectomy for hemispheric infarction. Neurology 2006; 67: 891-3.

Manuskriptet ble mottatt 25.7. 2008 og godkjent 30.7. 2009. Medisinsk redaktør Are Brean. 